\title{
Phosphorus-rich biochar produced through bean-worm skin waste pyrolysis enhances the adsorption of aqueous lead
}

Yubo Yan ${ }^{\mathrm{a}, \mathrm{b}}$, Binoy Sarkar ${ }^{\mathrm{c}}$, Lei Zhou ${ }^{\mathrm{a}}$, Ling Zhang ${ }^{\mathrm{d}}$, Qiao Li ${ }^{\mathrm{e}}$, Jianjun Yang ${ }^{\mathrm{b}^{*}}$, Nanthi Bolan ${ }^{\mathrm{f}, \mathrm{g}}$

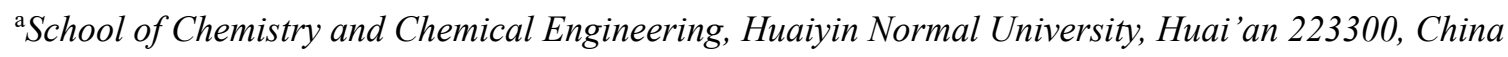

${ }^{\mathrm{b}}$ Institute of Environmental and Sustainable Development in Agriculture, Chinese Academy of Agricultural Science, Beijing 100081, China

${ }^{\mathrm{c}}$ Lancaster Environment Centre, Lancaster University, Lancaster, LA1 4YQ, United Kingdom

${ }^{\mathrm{d} S c h o o l ~ o f ~ H e a l t h, ~ J i a n g s u ~ F o o d ~ \& ~ P h a r m a c e u t i c a l ~ S c i e n c e ~ C o l l e g e, ~ H u a i ' a n ~ 223001, ~ C h i n a ~}$

${ }^{\mathrm{e} S c h o o l ~ o f ~ E n v i r o n m e n t a l ~ a n d ~ B i o l o g i c a l ~ E n g i n e e r i n g, ~ N a n j i n g ~ U n i v e r s i t y ~ o f ~ S c i e n c e ~ a n d ~ T e c h n o l o g y, ~}$

Nanjing 210094, China

${ }^{\mathrm{f}}$ Global Centre for Environmental Remediation, University of Newcastle, Callaghan Campus, NSW 2308, Australia

${ }^{\mathrm{g} C o o p e r a t i v e ~ R e s e a r c h ~ C e n t r e ~ f o r ~ H i g h ~ P e r f o r m a n c e ~ S o i l ~(S o i l ~ C R C), ~ C a l l a g h a n, ~ N S W ~ 2308, ~ A u s t r a l i a ~}$

\section{Corresponding author:}

Prof Jianjun Yang (yangjianjun@caas.cn) 


\section{Highlights}

> A novel phosphorus $(\mathrm{P})$ rich biochar (BWS-BC) was produced from bean-worm skin waste.

> BWS-BC was effective in adsorption of $\mathrm{Pb}(\mathrm{II})$ from wastewater.

> BWS-BC showed a fast initial adsorption rate in $\mathrm{Pb}(\mathrm{II})$ adsorption.

$>\mathrm{P}$ in BWS-BC played an important role in $\mathrm{Pb}(\mathrm{II})$ adsorption.

\section{Graphical abstract}

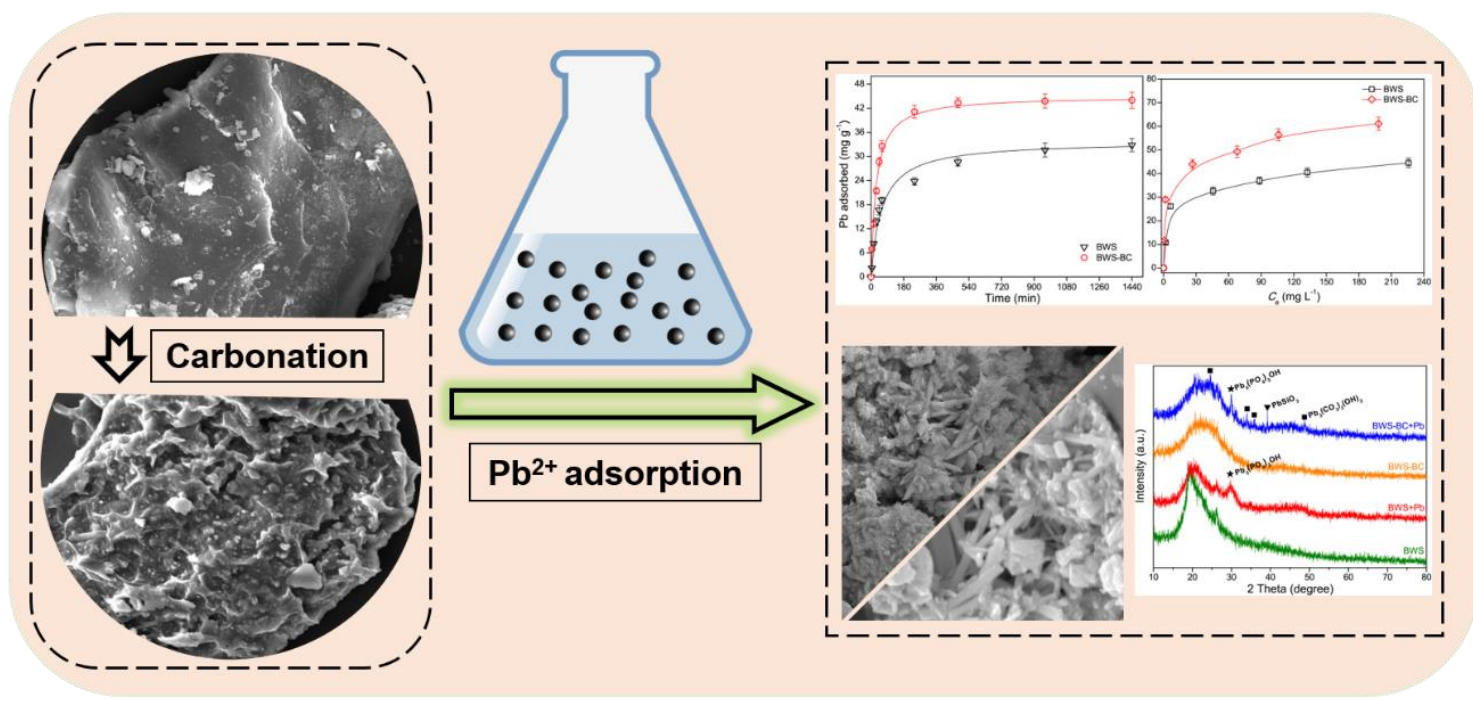


Abstract: In China, more than 10,000 tons of bean-worm powder, which is rich in protein (68.5\%) and essential amino acids (52.8\%), is consumed annually. Thus, a large amount of bean-worm skin waste is generated, and is often indiscriminately disposed of, potentially causing environment problems. In this study, bean-worm skin waste (BWS) was pyrolyzed at $500^{\circ} \mathrm{C}$ to produce biochar (BWS-BC), and the surface properties of BWS-BC were characterized using advanced spectroscopic techniques. $\mathrm{Pb}(\mathrm{II})$ adsorption properties of BWS and the corresponding biochar as a function of solution $\mathrm{pH}$, contact time, and equilibrium concentration of $\mathrm{Pb}(\mathrm{II})$ were examined using adsorption isotherm, kinetics, thermodynamic studies, and spectroscopic techniques. The maximum $\mathrm{Pb}$ (II) adsorption capacities based on the Langmuir isotherm model were calculated as 45 and $62 \mathrm{mg} \mathrm{g}^{-1}$ for BWS and BWS-BC, respectively, which were comparable to the values obtained for biochars derived from other agro-wastes. The adsorption feasibility, favorability and spontaneity of $\mathrm{Pb}(\mathrm{II})$, as derived from the thermodynamic parameters, indicated that chemisorption and precipitation (e.g., hydroxypyromorphite) were the main adsorption mechanism in case of BWS and BWS-BC, respectively. Thus, conversion of BWS to biochar for $\mathrm{Pb}(\mathrm{II})$ adsorption can be considered as a feasible, promising and high value-added approach for BWS recycling.

Keywords: $\mathrm{Pb}(\mathrm{II})$ removal, Waste bean worm skin, Biochar, Absorption mechanism, Wastewater treatment 


\section{Introduction}

Recycling of agricultural wastes as adsorbents for wastewater treatment has received much attention since these wastes are of low-cost, readily available and eco-friendly (Anastopoulos et al., 2019; Lingamdinne et al., 2016). For example, Fernández-López et al. (2019) showed that agro-waste from globe artichoke was effective in adsorbing aqueous $\mathrm{Pb}(\mathrm{II}), \mathrm{Cu}(\mathrm{II})$ and Cd(II). Wierzba and Kłos (2019) demonstrated the possibility of utilization of brewer's spent grain for the adsorption of aqueous heavy metals, and its adsorption effectiveness was related to the presence of other cations in the wastewater. Semerjian (2018) found that adsorption of heavy metals by natural pine sawdust (Pinus halepensis) was spontaneous and endothermic, and the adsorption capacity of $\mathrm{Pb}(\mathrm{II})$ and $\mathrm{Cu}(\mathrm{II})$ was 13.48 and $9.59 \mathrm{mg} \mathrm{g}^{-1}$, respectively. Gorgievski et al. (2013) reported that wheat straw could be a potential adsorbent to remove heavy metals from weakly acidic effluents, and its adsorption capacity ranged from 2.49 to 4.9 $\mathrm{mg} \mathrm{g}^{-1}$. Vilardi et al. (2018) used banana peel powder to adsorb heavy metals, and its maximum adsorption capacity of $\mathrm{Pb}(\mathrm{II})$ and $\mathrm{Cu}(\mathrm{II})$ was 10.9 and $12.85 \mathrm{mg} \mathrm{g}^{-1}$, respectively. There are still a lot of similar studies such as the utilization of watermelon rind, potato peel, cucumber peel and peanut shell as adsorbents (Anastopoulos et al., 2019). A general survey of relevant literature showed that (i) recent research interests in this topic were principally focused on the plant-based wastes, but little on insect-based wastes, and (ii) majority of biomass adsorbents were often restricted from practical applications due to the low adsorption capacity and poor stability of the adsorbents.

Shortage of food resources (especially for animal protein), as a result of the growth of world population and further degradation of the environment, has impacted the human societies for 
decades. Nowadays, edible insects have been regarded as a promising alternative food resources in many regions of the world by virtue of their nutritive values (e.g., high protein content, sufficient minerals), socioeconomic advantages (e.g., requirement of less cost, water and space in insect farming compared to livestock farming), and environmental benefits (e.g., less emission of greenhouse gases and ammonia in insect farming) (Govorushko, 2019). Bean worm (Clanis bilineata) larva, which is widely consumed in North Jiangsu Province of China, contains protein level of $68.5 \%$ [dry weight ( $\mathrm{dw}$ ) basis] and essential amino acid level of $52.8 \%$ $(\mathrm{dw})$, both of which are greater than those of milk and eggs (Xia et al., 2012). In China, more than 10,000 tons of bean worms are consumed every year, and about 2000 tons of skin waste is generated, which is often indiscriminately disposed of, potentially causing environment problems (e.g., pathogen, stench) (Yan et al., 2020). Hence, it is of urgency and significance to dispose the waste bean worm skin safely, and in economically viable way.

Traditional methods of animal carcass and waste disposal (e.g., burial, incineration and composting) present significant limitations, such as release of infectious agents into the surface and ground water, emission of gaseous pollutants, and long processing time (Gwyther et al., 2011; Zhang et al., 2018). In comparison, pyrolysis can effectively destroy pathogens, shorten the waste processing time, and produce clean energy (e.g., bio-oil, syngas) and stable biochar. Pyrolysis has thus been regarded as a promising alternative technology for the disposal of animal carcasses and wastes (Chen et al., 2020; Gwyther et al., 2011; Zhang et al., 2018). Recent studies have demonstrated that conversion of biomass feedstocks to biochar could generate large specific surface area (SSA), active sorption sites, and modified surface electric charge, thus facilitating sorption of heavy metals (Cao et al., 2019). For example, Lee et al. (2015) 
reported that the maximum adsorption amount of $\mathrm{Pb}(\mathrm{II})$ on peat moss increased by $10.6 \%$ after converting the feedstock to biochar via pyrolysis. Amin (2018) showed that the maximum adsorption amount of $\mathrm{Pb}(\mathrm{II})$ on banana peel derived biochar $\left(227.27 \mathrm{mg} \mathrm{g}^{-1}\right)$ was significantly greater than raw banana peel $\left(2.18 \mathrm{mg} \mathrm{g}^{-1}\right.$ ) (Anwar et al., 2010). Cao et al. (2019) found tenfold large SSA of wheat straw after pyrolysis, and that adsorption capacity of wheat straw increased from 46.33 to $119.55 \mathrm{mg} \mathrm{g}^{-1}$.

Therefore, the overall aim of this work is to convert the bean worm skin waste (BWS) into a high-value biochar (BWS-BC), and to investigate the difference of adsorption properties between BWS and BWS-BC toward aqueous $\mathrm{Pb}(\mathrm{II})$. Specifically, the effects of $\mathrm{pH}$, contact time, input $\mathrm{Pb}(\mathrm{II})$ concentration and temperature on $\mathrm{Pb}(\mathrm{II})$ adsorption were investigated by batch experiments. Subsequently, several classical adsorption models (e.g., kinetic and isotherm) were studied for understanding the $\mathrm{Pb}(\mathrm{II})$ adsorption process in depth. Furthermore, appropriate characterization techniques were employed to investigate the mechanism that were responsible for the adsorption of $\mathrm{Pb}(\mathrm{II})$ on the studied adsorbents.

\section{Materials and methods}

\subsection{Materials}

BWS samples were obtained from a farmers' market in North Jiangsu Province, China. Before using, the samples were subjected to stepwise pretreatment processes, comprising rinsed with tap water, air-dried to constant weight, and ground to less than $0.15 \mathrm{~mm}$ powder. BWS$\mathrm{BC}$ was prepared by pyrolyzing the pre-treated BWS powder at $500{ }^{\circ} \mathrm{C}$ for $4 \mathrm{~h}$ under oxygen limited condition in a quartz tube furnace with a heating rate of $5{ }^{\circ} \mathrm{C} \min ^{-1}$.

A simulated wastewater containing $1000 \mathrm{mg} \mathrm{L}^{-1} \mathrm{~Pb}(\mathrm{II})$ was prepared by dissolving the 
accurate amount of $\mathrm{Pb}\left(\mathrm{NO}_{3}\right)_{2}$ to deionized water. The desired $\mathrm{Pb}$ (II) concentrations in the subsequent experiments were obtained by diluting the simulated wastewater using deionized water. All chemical reagents (analytical grade) used in this study (e.g., $\mathrm{NaOH}, \mathrm{NaCl}, \mathrm{HNO}_{3}$ ) were obtained from Sinopharm Chemical Reagent Co. Ltd., Shanghai, China.

\subsection{Characterization}

The zeta potential values of BWS and BWS-BC were measured by Zetasizer (Nano series, Malvern, England). The information on functional groups, surface morphology and mineral composition of the two adsorbents pre- and post- $\mathrm{Pb}(\mathrm{II})$ adsorption was determined by Fouriertransform infrared spectroscopy (FTIR, Nicolet is50, Thermo Scientific, USA), scanning electron microscopy linked to energy dispersive spectroscopy (SEM-EDS, Quanta 250FEG, FEI, USA), and X-ray diffraction (XRD, EPSILON5, PANalytical, Netherlands), respectively. The $\mathrm{Pb}(\mathrm{II})$ concentration in solutions was determined via inductively coupled plasma optical emission spectrometry (ICP-OES, Optima 7000DV, PerkinElmer, USA). In addition, the basic physicochemical properties, including the $\mathrm{pH}$, ash contents, cation exchange capacity (CEC), elemental contents $(\mathrm{C}, \mathrm{N}, \mathrm{H}, \mathrm{O}$ and $\mathrm{P})$ and SSA of BWS and BWS-BC were determined by the methods described in our previous work (Yan et al., 2020), and the results are shown in Table S1 (Supplementary Materials).

\subsection{Batch experiments}

Batch adsorption experiments were conducted in $50 \mathrm{~mL}$ Corning centrifuge tubes with a mixture of $0.05 \mathrm{~g}$ adsorbent and $30 \mathrm{~mL} \mathrm{Pb(II)-containing} \mathrm{solution}\left(0.01 \mathrm{~mol} \mathrm{~L}^{-1} \mathrm{NaCl}\right.$ as the background electrolyte to maintain the ionic strength) on a rotating shaker at constant rotating

speed of $200 \mathrm{rpm}$. The adsorption amount of $\mathrm{Pb}(\mathrm{II})$ at time $t\left(q_{\mathrm{t}}, \mathrm{mg} \mathrm{g}^{-1}\right)$ was calculated 
according to:

$q_{\mathrm{t}}=\frac{\left(C_{0}-C_{\mathrm{t}}\right) V}{m}$

where, $C_{0}\left(\mathrm{mg} \mathrm{L}^{-1}\right)$ is the initial $\mathrm{Pb}(\mathrm{II})$ concentration; $C_{\mathrm{t}}\left(\mathrm{mg} \mathrm{L}^{-1}\right)$ is the $\mathrm{Pb}(\mathrm{II})$ concentration at time $t ; V(\mathrm{~L})$ is the volume of $\mathrm{Pb}(\mathrm{II})$-containing solution; $m(\mathrm{~g})$ is the weight of BWS and BWS$\mathrm{BC}$.

To investigate the effect of $\mathrm{pH}(2.0 \sim 6.0)$ on adsorption, each adsorbent was mixed with 100 $\mathrm{mg} \mathrm{Pb}$ (II) $\mathrm{L}^{-1}$ solution at $25^{\circ} \mathrm{C}$ for $24 \mathrm{~h}$, and the initial $\mathrm{pH}$ value of the solution was adjusted using $0.1 \mathrm{~mol} \mathrm{~L}^{-1} \mathrm{NaOH}$ and $0.1 \mathrm{~mol} \mathrm{~L}^{-1} \mathrm{HNO}_{3}$. To avoid the interference induced from $\mathrm{Pb}$ hydroxide species, the $\mathrm{pH}$ range of $2.0 \sim 6.0$ was selected in this study. The kinetic experiments were carried out by adding each adsorbent into $100 \mathrm{mg} \mathrm{Pb}(\mathrm{II}) \mathrm{L}^{-1}$ solution (pH $5.0 \pm 0.2$ ) at $25{ }^{\circ} \mathrm{C}$, relevant centrifuge tubes were withdrawn at the stated intervals of $5 \sim 1440 \mathrm{~min}$. The equilibrium experiments were performed by mixing adsorbents with various $\mathrm{Pb}(\mathrm{II})$ concentrations $\left(20 \sim 300 \mathrm{mg} \mathrm{L}^{-1}\right.$, $\left.\mathrm{pH} 5.0 \pm 0.2\right)$ at $25^{\circ} \mathrm{C}$ for $24 \mathrm{~h}$. Adsorption thermodynamic behavior was studied at different reaction temperatures $\left(10 \sim 40{ }^{\circ} \mathrm{C}\right)$ at $\mathrm{pH} 5.0 \pm 0.2$ for $24 \mathrm{~h}$. After adsorption, the suspension was promptly filtered by $0.22 \mu \mathrm{m}$ membrane filters, and the filtrate was collected and diluted for determination of residual $\mathrm{Pb}$ (II) concentration. All experiments were performed in triplicate, and mean results are presented.

\section{Results and discussion}

\subsection{Effect of $p H$}

Solution $\mathrm{pH}$ can affect both the surface charge of adsorbents and chemical speciation of heavy metal ions, leading to the change in adsorption performance. The model established using Visual MINTEQ software (Fig. 1a) showed that $\mathrm{Pb}(\mathrm{II})$ was the primary species in the $\mathrm{pH}$ range 
of $2.0 \sim 6.0$. The effect of solution $\mathrm{pH}$ on $\mathrm{Pb}(\mathrm{II})$ adsorption by BWS and BWS-BC is shown in Fig. 1b. The adsorption of $\mathrm{Pb}(\mathrm{II})$ on $\mathrm{BWS}$ and $\mathrm{BWS}-\mathrm{BC}$ was both $\mathrm{pH}$ dependent, but the impact extent was different. The adsorption amount of BWS increased significantly with raising $\mathrm{pH}$ from 2.0 to 5.0, and then tended to remain constant. The $\mathrm{Pb}(\mathrm{II})$ adsorption amount of BWS-BC had a slight fluctuation at $\mathrm{pH}$ values $>3.0$, implying a good buffering capacity for BWS-BC. Moreover, the amount of $\mathrm{Pb}(\mathrm{II})$ adsorbed on BWS-BC $\left(26.4 \sim 45.8 \mathrm{mg} \mathrm{g}^{-1}\right)$ was higher than that of BWS $\left(11.2 \sim 33.4 \mathrm{mg} \mathrm{g}^{-1}\right)$ over the entire $\mathrm{pH}$ range. These phenomena could be attributed to the following three reasons (Rwiza et al., 2018; Yan et al., 2015). Initially, the relatively low $\mathrm{pH}$ condition caused competition between proton and $\mathrm{Pb}$ (II) for the confined active sites on the surface of adsorbents. Moreover, the partial dissolution of adsorbents at highly acidic environment let to the reduction in surface active sites. Finally, as shown in Fig. 1b, the points of zero charge $\left(\mathrm{pH}_{\mathrm{pzc}}\right)$ of BWS and BWS-BC were 3.4 and 2.1, respectively. At $\mathrm{pH}<3.4$, an electrostatic repulsion inhibited the adsorption of positively charged $\mathrm{Pb}(\mathrm{II})$ on the positively charged surface of BWS. As pH values increased, the negatively charged sites on the surface of BWS enhanced gradually, thus the strong electrostatic attraction occurred, which was favorable to $\mathrm{Pb}(\mathrm{II})$ adsorption. A similar explanation was also valid for the case of BWS-BC. Notably, all zeta potentials of BWS-BC were much lower than that of BWS, indicating that BWS-BC possessed a higher binding ability to $\mathrm{Pb}(\mathrm{II})$ compared to $\mathrm{BWS}$.

\subsection{Adsorption kinetics}

Fig. 2 shows the effect of contact time on $\mathrm{Pb}(\mathrm{II})$ adsorbed by BWS and BWS-BC. It was apparent that the adsorption curves increased steeply within first $60 \mathrm{~min}$, which indicated that abundant adsorption sites on the external surface of adsorbents were rapidly occupied by $\mathrm{Pb}(\mathrm{II})$ 
via physisorption (Ahmad et al., 2014; Wang et al., 2015; Xiao et al., 2017). As time proceeded, the adsorption curves increased slowly, and finally reached a pseudo equilibrium within 960 and 480 min for BWS and BWS-BC, respectively. This may be ascribed to the irreversible chemisorption toward the end of the adsorption process (Ahmad et al., 2014; Wang et al., 2015; Xiao et al., 2017). To better understand the rate-controlling steps responsible for $\mathrm{Pb}(\mathrm{II})$ adsorption on BWS and BWS-BC, the pseudo-first order and pseudo-second order kinetic models (Ho et al., 1996; Li et al., 2007) were explored to fit the experimental data. The linearized equations of the above models were presented in Supplementary Materials.

The fitted parameters of kinetic models at $25{ }^{\circ} \mathrm{C}$ are presented in Table S2. The coefficients of determination $\left(R^{2}\right)$ predicted by the pseudo-second order model for BWS (0.9982) and BWS$\mathrm{BC}(0.9999)$ were both higher than those of the pseudo-first order model (0.9613 and 0.9103 for BWS and BWS-BC, respectively). Furthermore, the theoretical adsorption capacities ( $\left.q_{\mathrm{e}, \text { cal }}\right)$ predicted from the pseudo-second order model was 33.78 and $45.05 \mathrm{mg} \mathrm{g}^{-1}$ for BWS and BWS$\mathrm{BC}$, respectively, which were in good agreement with the values obtained in this study $(32.82$ and $43.98 \mathrm{mg} \mathrm{g}^{-1}$ for BWS and BWS-BC, respectively). These results suggested that the adsorption data of $\mathrm{Pb}(\mathrm{II})$ on both adsorbents could be suitably represented by the pseudo-second order model, implying that the rate-limiting steps over two adsorption processes were controlled by chemisorption. Similar results were obtained by Zhou et al. (2018) who revealed that the adsorption process of $\mathrm{Cu}(\mathrm{II})$ and $\mathrm{Cd}(\mathrm{II})$ by ferromanganese binary oxide-biochar composites was also well-described by the pseudo-second order model. In addition, the calculated initial adsorption rate $(h)$ values followed the order of BWS-BC $\left(1.66 \mathrm{mg} \mathrm{g}^{-1} \mathrm{~min}^{-1}\right)>\mathrm{BWS}(0.55 \mathrm{mg}$ $\mathrm{g}^{-1} \min ^{-1}$ ), indicating that the pyrolysis of BWS could significantly enhance the initial 
adsorption rate of $\mathrm{BWS}-\mathrm{BC}$ toward $\mathrm{Pb}(\mathrm{II})$.

\subsection{Adsorption isotherms}

Fig. 3a shows the effect of equilibrium concentrations on $\mathrm{Pb}(\mathrm{II})$ adsorption by BWS and BWS-BC. When $C_{\mathrm{e}}<45 \mathrm{mg} \mathrm{L}^{-1}$, the amounts of $\mathrm{Pb}(\mathrm{II})$ adsorbed on the adsorbents were found to increase remarkably. This could be ascribed to the sufficient active sites on the surface of the adsorbents during this period. On the other hand, as the values of $C_{\text {e }}$ continued to increase, available active adsorption sites on the surface of the adsorbents tended to saturate, therefore resulting in a dynamic equilibrium of adsorption capacity for each adsorbent. Similar observation was reported by Cheng et al. (2016). To further explore the adsorption process of $\mathrm{Pb}$ (II) on BWS and BWS-BC, three classical isotherm models including the Langmuir, Freundlich and Dubinin-Radushkevich (D-R) (Gorgievski et al., 2013; Kapnisti et al., 2018; Yan et al., 2020) models were employed to simulate the experimental data. The linearized forms of these models were shown in Supplementary Materials.

The fitting curves of BWS and BWS-BC are plotted in Fig. 3b Fig. 3d, and their related parameters are presented in Table S3. The Langmuir model exhibited the best fit for both the adsorbents with the highest coefficients of determination $\left(R^{2}>0.99\right)$. The Langmuir model is associated with a fixed number of identical and energetically equivalent active sites on the homogeneous surface of adsorbents (Yan et al., 2015). Hence, it could be inferred that there was no lateral interaction between $\mathrm{Pb}(\mathrm{II})$ and the adsorbents, i.e., the adsorption energy level to $\mathrm{Pb}$ (II) was uniformly distributed on the surface of BWS and BWS-BC. The maximum adsorption capacities $\left(q_{\max }\right)$ of BWS and BWS-BC toward $\mathrm{Pb}(\mathrm{II})$ were 45.45 and $61.73 \mathrm{mg} \mathrm{g}^{-1}$, respectively, which were comparable with other similar adsorbents (Table S4), indicating a 
good potential application of BWS-BC in practical wastewater treatment. The separation factor $\left(R_{\mathrm{L}}\right)$ (Supplementary Materials) plays an important role in evaluating the favorability of adsorption. The adsorption is favorable when $0<R_{\mathrm{L}}<1$, while $R_{\mathrm{L}}=1, R_{\mathrm{L}}>1$ and $R_{\mathrm{L}}=0$ correspond to linear, unfavorable and irreversible adsorption, respectively (Xiong et al., 2019). The $R_{\mathrm{L}}$ values for $\mathrm{BWS}$ and $\mathrm{BWS}-\mathrm{BC}$ were calculated as $0.04 \sim 0.37$ and $0.02 \sim 0.28$, respectively, where all values fell within the range of $0 \sim 1$, confirming the favorable adsorption of $\mathrm{Pb}$ (II) on $\mathrm{BWS}$ and $\mathrm{BWS}-\mathrm{BC}$. Notably, the $R_{\mathrm{L}}$ values of $\mathrm{BWS}-\mathrm{BC}$ were much smaller than those of BWS, indicating a higher binding affinity between $\mathrm{Pb}(\mathrm{II})$ and BWS-BC (Zhou et al., 2018).

Additionally, the $1 / n$ and $K_{\mathrm{F}}$ obtained from the Freundlich equation could be the indicators of adsorption favorability, such as $0<1 / n<1$ indicates a favorable adsorption (Yan et al., 2020). In this study, the $1 / n$ values of BWS and BWS-BC ranged between 0 to 0.3 , indicating favorable adsorption of $\mathrm{Pb}(\mathrm{II})$ by the two adsorbents (Ding et al., 2016). The $K_{\mathrm{F}}$ values followed the order: BWS-BC $>$ BWS, also suggesting a relatively stronger cohesive force between BWS-BC and $\mathrm{Pb}(\mathrm{II})$, i.e., the pyrolysis of BWS could significantly enhance the adsorption affinity toward $\mathrm{Pb}(\mathrm{II})$.

The mean free energy constant $(E)$ predicted from the D-R equation could give important information about the adsorption mechanisms, such as physical adsorption when $E<8 \mathrm{~kJ} / \mathrm{mol}$, and chemical adsorption when $E>8 \mathrm{~kJ} / \mathrm{mol}$ (Ding et al., 2016). In the present study, the values of $E$ were 14.67 and $15.52 \mathrm{~kJ} \mathrm{~mol}^{-1}$ for BWS and BWS-BC, respectively. Both these values exceeded $8 \mathrm{~kJ} \mathrm{~mol}^{-1}$, indicating that the adsorption of $\mathrm{Pb}(\mathrm{II})$ on BWS and BWS-BC took place chemically, which was consistent with the results of the pseudo-second order model fitting of 
the kinetic data.

\subsection{Adsorption thermodynamics}

Analysis of thermodynamic parameters not only judges the nature of adsorption process, but also obtains the information on predominant mechanisms occurring in the adsorption reaction (e.g., physical interaction, chemical interaction) (Rahmani-Sani et al., 2020). In the present study, thermodynamic parameters including Gibbs free energy change $\left(\Delta G^{\mathrm{o}}, \mathrm{kJ} \mathrm{mol}^{-1}\right)$, enthalpy change $\left(\Delta H^{\mathrm{o}}, \mathrm{kJ} \mathrm{mol}^{-1}\right)$ and entropy change $\left(\Delta S^{\mathrm{o}}, \mathrm{kJ} \mathrm{mol}^{-1} \mathrm{~K}^{-1}\right)$ were calculated from the Van't Hoff equation (shown in Supplementary Materials) at 283, 298 and $313 \mathrm{~K}$ temperatures.

The corresponding thermodynamic parameters are listed in Table S5. The $\Delta G^{\mathrm{o}}$ values negatively increased from -0.28 to $-9.56 \mathrm{~kJ} \mathrm{~mol}^{-1}$ and -4.31 to -20.84 with temperature rose from 283 to $313 \mathrm{~K}$ for BWS and BWS-BC, respectively. These results indicated that the adsorption of $\mathrm{Pb}(\mathrm{II})$ on BWS and BWS-BC was thermodynamically favorable and highly spontaneous at high working temperature. The positive $\Delta H^{\mathrm{o}}$ values were indicators of the endothermic nature for $\mathrm{Pb}(\mathrm{II})$ adsorption on $\mathrm{BWS}$ and BWS-BC. According to $\Delta H^{\circ}$ values, the adsorption types could be identified as physical adsorption $\left(2.1<\Delta H^{\mathrm{o}}<20.9 \mathrm{~kJ} \mathrm{~mol}^{-1}\right)$ and chemical adsorption $\left(20.9<\Delta H^{\mathrm{o}}<418.4 \mathrm{~kJ} \mathrm{~mol}^{-1}\right)$ (Yan et al., 2015). The obtained $\Delta H^{\mathrm{o}}$ values for BWS $(86.84 \mathrm{~kJ}$ $\left.\mathrm{mol}^{-1}\right)$ and BWS-BC $\left(149.74 \mathrm{~kJ} \mathrm{~mol}^{-1}\right)$ ranged from 20.9 to $418.4 \mathrm{~kJ} \mathrm{~mol}^{-1}$, indicating chemical interaction taking place between $\mathrm{Pb}(\mathrm{II})$ and the adsorbents, which was in accord with the kinetic and isotherm results. The positive $\Delta \mathrm{S}^{\circ}$ values for BWS $\left(0.31 \mathrm{~kJ} \mathrm{~mol}^{-1} \mathrm{~K}^{-1}\right)$ and BWS-BC $(0.54$ $\mathrm{kJ} \mathrm{mol}^{-1} \mathrm{~K}^{-1}$ ) suggested an increased extent of randomness at the interfaces of $\mathrm{Pb}(\mathrm{II})-\mathrm{BWS}$ and $\mathrm{Pb}(\mathrm{II})-\mathrm{BWS}-\mathrm{BC}$, which could facilitate the adsorption. Interestingly, the absolute values of all the thermodynamic data for BWS-BC were greater than that of BWS, reflecting that the 
adsorption feasibility, favorability and spontaneity for $\mathrm{BWS}$ to $\mathrm{Pb}(\mathrm{II})$ could be significantly enhanced by pyrolysis.

\subsection{Possible adsorption mechanism}

The surface functional group information of the adsorbents pre- and post- $\mathrm{Pb}(\mathrm{II})$ adsorption is presented in Fig. 4. For BWS, the broad FTIR bands in the range of $3280 \sim 3430 \mathrm{~cm}^{-1}$ were attributed to the stretching vibrations of $\mathrm{O}-\mathrm{H}$ and $\mathrm{N}-\mathrm{H}$ groups (Wu et al., 2017). The bands at 2928 and $1315 \mathrm{~cm}^{-1}$ were associated with the stretching vibrations of $\mathrm{C}-\mathrm{H}$ and $\mathrm{N}-\mathrm{H}$ bonds, respectively (Ali et al., 2020; Fernández-López et al., 2019). The bands at 1650 and $1542 \mathrm{~cm}^{-1}$ were corresponding to amide I (band of $\mathrm{C}=\mathrm{O}$ stretching vibration) and amide II (bands of $\mathrm{C}-\mathrm{N}$ stretching vibration and N-H bending vibration), respectively (Saravana et al., 2018). The band at $1446 \mathrm{~cm}^{-1}$ was assigned to the out-of-plane bending vibration for carbonates (Lee et al., 2019; Xu et al., 2013). The bands at 1387 and $1251 \mathrm{~cm}^{-1}$ were ascribed to the deformation vibrations of C-H and O-H bonds, respectively (Gao et al., 2020; $\mathrm{Wu}, 2012)$. The special absorption bands observed at 1155 and $895 \mathrm{~cm}^{-1}$ represented the $\beta(1 \rightarrow 4)$ glycosidic bond (Wu et al., 2017). The bands at 1110, 1070 and $570 \mathrm{~cm}^{-1}$ indicated the occurrence of P-O bond (Lee et al., 2019; Lei et al., 2019). After $\mathrm{Pb}$ (II) adsorption, the characteristic spectral bands at 1251, 1387, 1542 and $570 \mathrm{~cm}^{-1}$ were shifted to $1235,1378,1538$ and $476 \mathrm{~cm}^{-1}$, respectively, indicative of the participation of $\mathrm{O}-\mathrm{H}, \mathrm{C}-\mathrm{H}, \mathrm{N}-\mathrm{H}, \mathrm{C}-\mathrm{N}$, and $\mathrm{P}-\mathrm{O}$ bonds in adsorption of $\mathrm{Pb}$ (II) on BWS. For BWS-BC, most of the characteristic IR bands in BWS disappeared and/or weakened, meanwhile, a new intense band emerged at $1582 \mathrm{~cm}^{-1}$, which was characteristic of $\mathrm{C}=\mathrm{C}$ bond in aromatic ring (Gao et al., 2020). In addition, the stronger bands at 3421 (phenolic O-H bond) and 1111 (P-O bond) $\mathrm{cm}^{-1}$ for BWS-BC compared to that of BWS indicated the reinforcement 
of aromatization degree and P exposure of BWS owing to pyrolysis reaction. In the case of BWS-BC loaded with $\mathrm{Pb}(\mathrm{II})$, a significant shift was observed on $\mathrm{P}-\mathrm{O}$ bond at 1109 to $1087 \mathrm{~cm}^{-}$ ${ }^{1}$ region, and a new characteristic adsorption band of $\mathrm{P}-\mathrm{O}$ bond occurred at $476 \mathrm{~cm}^{-1}$, both implying the importance of $\mathrm{P}$ in $\mathrm{Pb}$ (II) adsorption on BWS-BC. As shown in Table S1, BWS$\mathrm{BC}$ had higher $\mathrm{P}$ content than $\mathrm{BWS}$, which might have facilitated a greater $\mathrm{Pb}$ adsorption by BWS-BC over BWS.

The SEM images of two adsorbents before and after $\mathrm{Pb}(\mathrm{II})$ adsorption are shown in Fig. 5. It was observed that BWS possessed a laminated structure with a relatively smooth surface (Fig. 5a). As seen from Fig. 5d, the presence of rough surfaces on the laminated structure of BWS$\mathrm{BC}$ was due to partial decomposition of the organic components in BWS after pyrolysis (Shen et al., 2019), which also was an evidence of the increase in SSA (Table S1). After Pb(II) adsorption, the laminated structures were converted into a lot of fragments in both BWS and BWS-BC (Fig. 5b and e). Meanwhile, numerous rod-shaped crystallites were generated and aggregated on the surface of the adsorbents (Fig. 5c and f). Furthermore, the EDS spectra (inset in Fig. 5c and f) showed that the fine crystallites primarily consisted of $\mathrm{C}, \mathrm{Pb} \mathrm{O}, \mathrm{P}$, and $\mathrm{Si}$. The XRD results of the post-adsorption samples, as illustrated in Fig. 6, confirmed this observation. New characteristic diffraction reflections were indexed to the precipitation of $\mathrm{Pb}-\mathrm{P}-\mathrm{O}, \mathrm{Pb}-\mathrm{C}-\mathrm{O}$ and $\mathrm{Pb}-\mathrm{Si}-\mathrm{O}$ compounds. The emergence of hydroxypyromorphite $\left(\mathrm{Pb}_{5}\left(\mathrm{PO}_{4}\right)_{3} \mathrm{OH}\right)$, hydrocerussite $\left(\mathrm{Pb}_{3}\left(\mathrm{CO}_{3}\right)_{2}(\mathrm{OH})_{2}\right)$ and alamosite $\left(\mathrm{PbSiO}_{3}\right)$ was noticed for the post-adsorption BWS-BC sample, while only hydroxypyromorphite was involved in the case of BWS. Overall, the pyrolysis could significantly enhance the exposure of active sites (e.g., P, Si) in BWS, which played the primary role in $\mathrm{Pb}(\mathrm{II})$ adsorption on BWS-BC. 


\section{Conclusions}

Pyrolysis was proved to be an effective approach in improving the adsorption performance of BWS toward $\mathrm{Pb}(\mathrm{II})$. In comparison with BWS, the good buffering ability of BWS-BC due to the higher $\mathrm{pH}$ value of the later adsorbent than the former led to the less fluctuation of $\mathrm{pH}$ values in the adsorption system (initial $\mathrm{pH}=2.0$ to 6.0 ). Also, the reduction in zeta potentials for BWS-BC strengthened the electrostatic attraction of the adsorbent to solution $\mathrm{Pb}(\mathrm{II})$. The results of adsorption kinetics showed a faster initial adsorption rate for BWS-BC (1.66 mg g $\mathrm{g}^{-1}$ $\left.\min ^{-1}\right)$ than BWS $\left(0.55 \mathrm{mg} \mathrm{g}^{-1} \mathrm{~min}^{-1}\right)$. The maximum adsorption capacities calculated from the Langmuir isotherm equation were 45.45 and $61.73 \mathrm{mg} \mathrm{g}^{-1}$, respectively, which are highly competitive with other similar adsorbents. The thermodynamic study suggested that both BWS and BWS-BC could favorably, spontaneously and endothermically adsorb solution $\mathrm{Pb}(\mathrm{II})$. Moreover, pyrolysis could significantly enhance the exposure of surface active sites of BWS, thus enhancing the $\mathrm{Pb}$ (II) adsorption. Specially, BWS-BC could intensely adsorb solution $\mathrm{Pb}$ (II) through precipitation of hydroxypyromorphite, hydrocerussite and alamosite, while forming hydroxypyromorphite for BWS.

\section{Acknowledgments}

The authors would like to acknowledge the National Natural Science Foundation of China (41907133), Jiangsu Provincial Natural Science Foundation (BK20191057, HAB201827), National Key Research and Development Program of China (2018YFD0800305, 2016YFD0800400), Agricultural Science and Technology Innovation Program of Chinese Academy of Agricultural Sciences (2018-2021), China Postdoctoral Science Foundation (2018M641557), Jiangsu Provincial Natural Science Foundation for Universities 
(19KJD610002), and Open Funds of Provincial Laboratories (JSEFM201808, BEETKC1906) for their financial support.

\section{References}

Ahmad, M., Rajapaksha, A.U., Lim, J.E., Zhang, M., Bolan, N., Mohan, D., Vithanage, M., Lee, S.S., Ok, Y.S., 2014. Biochar as a sorbent for contaminant management in soil and water: a review. Chemosphere 99, 19-33.

Ali, S., Rizwan, M., Shakoor, M.S., Jilani, A., Anjum, R., 2020. High sorption efficiency for $\mathrm{As}(\mathrm{III})$ and $\mathrm{As}(\mathrm{V})$ from aqueous solutions using novel almond shell biochar. Chemosphere $243,125330$.

Amin, M.T., Alazba, A.A., Shafiq, M., 2018. Removal of copper and lead using banana biochar in batch adsorption systems: Isotherms and kinetic studies. Arab. J. Sci. Eng. 43, 57115722.

Anastopoulos, I., Pashalidis, I., Hosseini-Bandegharaei, A., Giannakoudakis, D.A., Robalds, A., Usman, M., Escudero, L.B., Zhou, Y., Colmenares, J.C., Núñez-Delgado, A., Lima, E.C., 2019. Agricultural biomass/waste as adsorbents for toxic metal decontamination of aqueous solutions. J. Mol. Liq. 295, 111684.

Anwar, J., Shafique, U., Waheed-uz-Zaman, Salman, M., Dar, A., Anwar, S., 2010. Removal of $\mathrm{Pb}(\mathrm{II})$ and $\mathrm{Cd}(\mathrm{II})$ from water by adsorption on peels of banana. Bioresource Technol. 101, $1752-1755$.

Cao, Y., Xiao, W., Shen, G., Ji, G., Zhang, Y., Gao, C., Han, L., 2019. Carbonization and ball milling on the enhancement of $\mathrm{Pb}(\mathrm{II})$ adsorption by wheat straw: Competitive effects of ion exchange and precipitation. Bioresource Technol. 273, 70-76. 
Chen, H., Yang, X., Wang, H., Sarkar, B., Shaheen, S.M., Gielen, G., Bolan, N., Guo, J., Che, L., Sun, H., Rinklebe, J., 2020. Animal carcass- and wood-derived biochars improved nutrient bioavailability, enzyme activity, and plant growth in metal-phthalic acid ester cocontaminated soils: A trial for reclamation and improvement of degraded soils. Journal of Environmental Management 261, 110246.

Cheng, Q., Huang, Q., Khan, S., Liu, Y., Liao, Z., Li, G., Ok, Y.S., 2016. Adsorption of Cd by peanut husks and peanut husk biochar from aqueous solutions. Ecol. Eng. 87, 240-245.

Ding, Z., Wan, Y., Hu, X., Wang, S., Zimmerman, A.Z., Gao, B., 2016. Sorption of lead and methylene blue onto hickory biochars from different pyrolysis temperatures: Importance of physicochemical properties. J. Ind. Eng. Chem. 37, 261-267.

Fernández-López, J.A., Fernández-López, J.M., Roca, M.J., Miñarro, M.D., 2019. Taguchi design-based enhancement of heavy metals bioremoval by agroindustrial waste biomass from artichoke. Sci. Total Environ. 653, 55-63.

Gao, R., Xiang, L., Hu, H., Fu, Q., Zhu, J., Liu, Y., Huang, G., 2020. High-efficiency removal capacities and quantitative sorption mechanisms of $\mathrm{Pb}$ by oxidized rape straw biochars. Sci. Total Environ. 699, 134262.

Gorgievski, M., Božić, D., Stanković, V., Štrbac, N., Šerbula, S., 2013. Kinetics, equilibrium and mechanism of $\mathrm{Cu}^{2+}, \mathrm{Ni}^{2+}$ and $\mathrm{Zn}^{2+}$ ions biosorption using wheat straw. Ecol. Eng. 58, $113-122$.

Govorushko, S., 2019. Global status of insects as food and feed source: A review. Trends Food Sci. Tech. 91, 436-445.

Gwyther, C.L., Williams, A.P., Golyshin, P.N., Edwards-Jones, G., Jones, D.L., 2011. The 
environmental and biosecurity characteristics of livestock carcass disposal methods: A review. Waste Manage. 31, 767-778.

Ho, Y.S., Wase, D.A.J., Forster, C.F., 1996. Kinetic studies of competitive heavy metal adsorption by sphagnum moss peat. Environ. Technol. 17, 71-77.

Lee, M., Park, J.H., Chung, J.W., 2019. Comparison of the lead and copper adsorption capacities of plant source materials and their biochars. J. Environ. Manage. 236, 118-124.

Lee, S., Park, J.H., Ahn, Y., Chung, J.W., 2015. Comparison of heavy metal adsorption by peat moss and peat moss-derived biochar produced under different carbonization conditions. Water Air Soil Poll. 226, 9.

Lei, S., Shi, Y., Qiu, Y., Che, L., Xue, C., 2019. Performance and mechanisms of emerging animal-derived biochars for immobilization of heavy metals. Sci. Total Environ. 646, 1281-1289.

Li, Q., Zhai, J., Zhang, W., Wang, M., Zhou, J., 2007. Kinetic studies of adsorption of Pb(II), $\mathrm{Cr}$ (III) and $\mathrm{Cu}(\mathrm{II})$ from aqueous solution by sawdust and modified peanut husk. J. Hazard. Mater. 141, 163-167.

Lingamdinne, L.P., Yang, J., Chang, Y., Koduru, J.R., 2016. Low-cost magnetized Lonicera japonica flower biomass for the sorption removal of heavy metals. Hydrometallurgy 165 , $81-89$

Kapnisti, M., Noli, F., Misaelides, P., Vourlias, G., Karfaridis, D., Hatzidimitriou, A., 2018. Enhanced sorption capacities for lead and uranium using titanium phosphates; sorption, kinetics, equilibrium studies and mechanism implication. Chem. Eng. J. 342, 184-195.

Rahmani-Sani, A., Singh, P., Raizada, P., Lima, E.C., Anastopoulos, I., Giannakoudakis, D.A., 
Sivamani, S., Dontsova, T.A., Hosseini-Bandegharaei, A., 2020. Use of chicken feather and eggshell to synthesize a novel magnetized activated carbon for sorption of heavy metal ions. Bioresource Technol. 297, 122452.

Rwiza, M.J., Oh, S., Kim, K., Kim, S.D., 2018. Comparative sorption isotherms and removal studies for $\mathrm{Pb}$ (II) by physical and thermochemical modification of low-cost agro-wastes from Tanzania. Chemosphere 195, 135-145.

Saravana, P.S., Ho, T.C., Chae, S., Cho, Y., Park, J., 2018. Deep eutectic solvent-based extraction and fabrication of chitin films from crustacean waste. Carbohyd. Polym. 195, $622-630$.

Semerjian, L., 2018. Removal of heavy metals $(\mathrm{Cu}, \mathrm{Pb})$ from aqueous solutions using pine (Pinus halepensis) sawdust: Equilibrium, kinetic, and thermodynamic studies. Environ. Technol. Inno. 12, 91-103.

Shen, Z., Hou, D., Jin, F., Shi, J., Fan, X., Tsang, D.C.W., Alessi, D.S., 2019. Effect of production temperature on lead removal mechanisms by rice straw biochars. Sci. Total Environ. 655, 751-758.

Vilardi, G., Palma, L.D., Verdone, N., 2018. Heavy metals adsorption by banana peels micropowder: Equilibrium modeling by non-linear models. Chinese J. Chem. Eng. 26, 455-464.

Wang, S., Gao, B., Li, Y., Mosa, A., Zimmerman, A.R., Ma, L.Q., Harris, W.G., Migliaccio, K.W., 2015. Manganese oxide-modified biochars: Preparation, characterization, and sorption of arsenate and lead. Bioresource Technol. 181, 13-17.

Wierzba, S., Kłos, A., 2019. Heavy metal sorption in biosorbents - Using spent grain from the brewing industry. J. Clean. Prod. 225, 112-120. 
Wu, S., 2012. Preparation of chitooligosaccharides from Clanis bilineata larvae skin and their antibacterial activity. Int. J. Biol. Macromol. 51, 1147-1150.

Wu, S., Lu, M., Wang, S., 2017. Antiageing activities of water-soluble chitosan from Clanis bilineatalarvae. Int. J. Biol. Macromol. 102, 376-379.

Xia, Z., Wu, S., Pan, S., Kim, J.M., 2012. Nutritional evaluation of protein from Clanis bilineata (Lepidoptera), an edible insect. J. Sci. Food Agric. 92, 1479-1482.

Xiao, Y., Xue, Y., Gao, F., Mosa, A., 2017. Sorption of heavy metal ions onto crayfish shell biochar: Effect of pyrolysis temperature, $\mathrm{pH}$ and ionic strength. J. Taiwan Inst. Chem. E. 80, 114-121.

Xiong, C., Wang, S., Sun, W., Li, Y., 2019. Selective adsorption of Pb(II) from aqueous solution using nanosilica functionalized with diethanolamine: Equilibrium, kinetic and thermodynamic. Microchem. J. 146, 270-278.

Xu, X., Cao, X., Zhao, L., 2013. Comparison of rice husk- and dairy manure-derived biochars for simultaneously removing heavy metals from aqueous solutions: Role of mineral components in biochars. Chemosphere 92, 955-961.

Yan, Y., Li, Q., Sun, X., Ren, Z., He, F., Wang, Y., Wang, L., 2015. Recycling flue gas desulphurization (FGD) gypsum for removal of $\mathrm{Pb}(\mathrm{II})$ and $\mathrm{Cd}(\mathrm{II})$ from wastewater. $\mathrm{J}$. Colloid Interface Sci. 457, 86-95.

Yan, Y., Zhang, L., Wang, Y., Wang, X., Wang, S., Li, Q., Liu, X., Xu, Y., Yang, J., Bolan, N., 2020. Clanis bilineata larvae skin-derived biochars for immobilization of lead: Sorption isotherm and molecular mechanism. Sci. Total Environ. 704, 135251.

Zhang, Y., Ma, Z., Yan, J., 2018. Influence of pork and bone on product characteristics during 
the fast pyrolysis of pig carcasses. Waste Manage. 75, 352-360.

Zhou, Q., Liao, B., Lin, L., Qiu, W., Song, Z., 2018. Adsorption of Cu(II) and Cd(II) from aqueous solutions by ferromanganese binary oxide-biochar composites. Sci. Total Environ. $615,115-122$.

\section{Figure captions}

Fig. 1 (a) The distribution of $\mathrm{Pb}$ species in solution ionic strength of $0.01 \mathrm{~mol} / \mathrm{L} \mathrm{NaNO}_{3}$ at $25^{\circ} \mathrm{C}$, and (b) the effect of $\mathrm{pH}$ on $\mathrm{Pb}(\mathrm{II})$ adsorption and the surface zeta potential curves of BWS and BWS-BC.

Fig. 2 The effect of contact time on $\mathrm{Pb}(\mathrm{II})$ adsorption on BWS and BWS-BC.

Fig. 3 (a) The effect of equilibrium adsorbate concentration on $\mathrm{Pb}(\mathrm{II})$ adsorption on BWS and BWS-BC, (b) Langmuir fit curves, (c) Freundlich fit curves, and (d) D-R fit curves.

Fig. 4 FTIR spectra of BWS and BWS-BC before and after $\mathrm{Pb}(\mathrm{II})$ adsorption.

Fig. 5 SEM-EDS images of (a) BWS, (b-c) BWS after Pb(II) adsorption, (d) BWS-BC, and (ef) BWS-BC after $\mathrm{Pb}(\mathrm{II})$ adsorption.

Fig. 6 XRD patterns of BWS and BWS-BC before and after $\mathrm{Pb}(\mathrm{II})$ adsorption. 


\section{Figures}
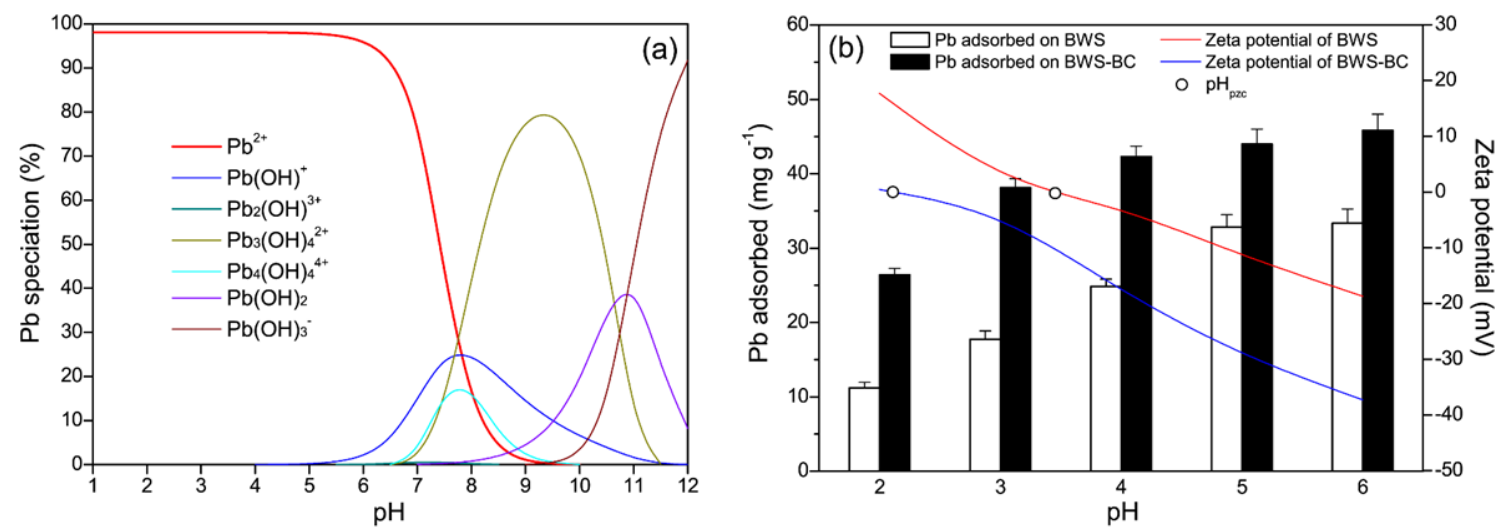

Fig. 1

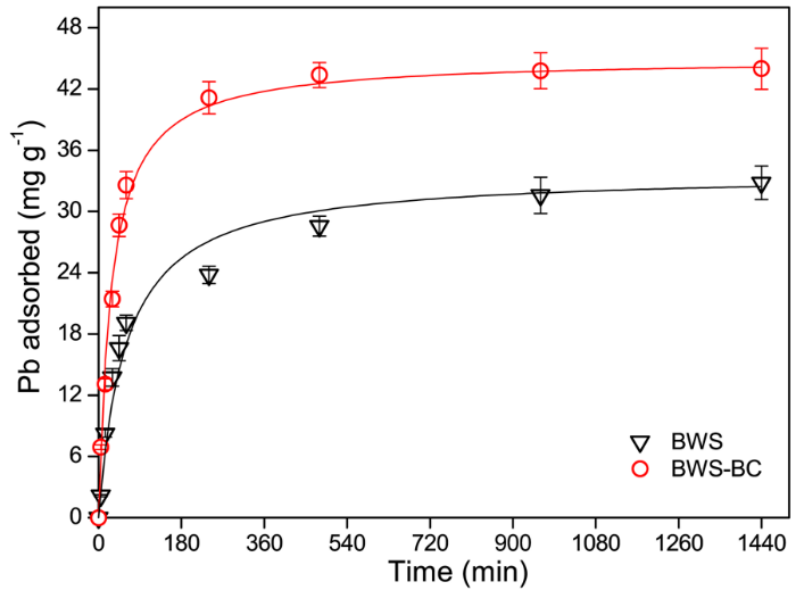

Fig. 2 

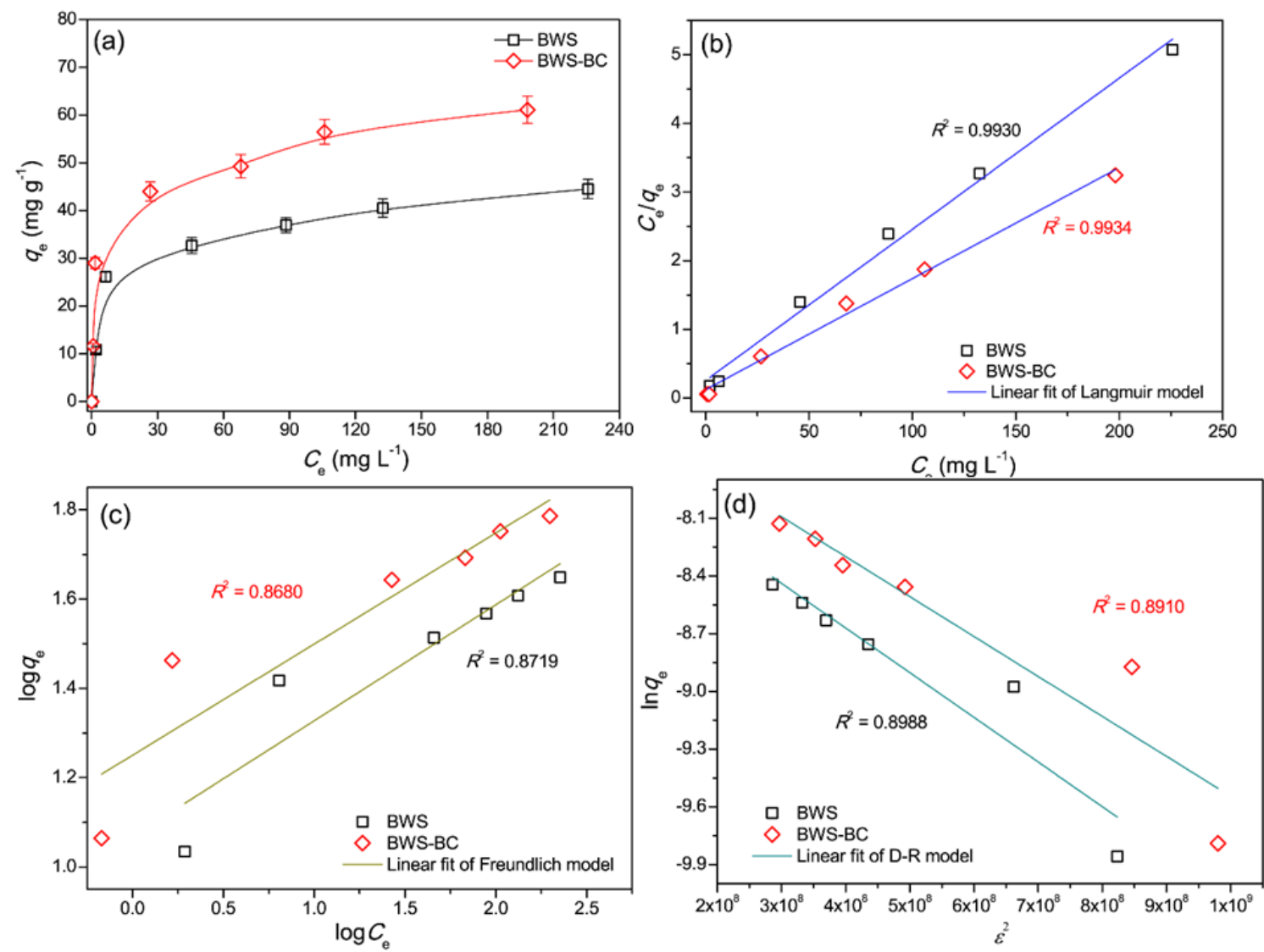

Fig. 3

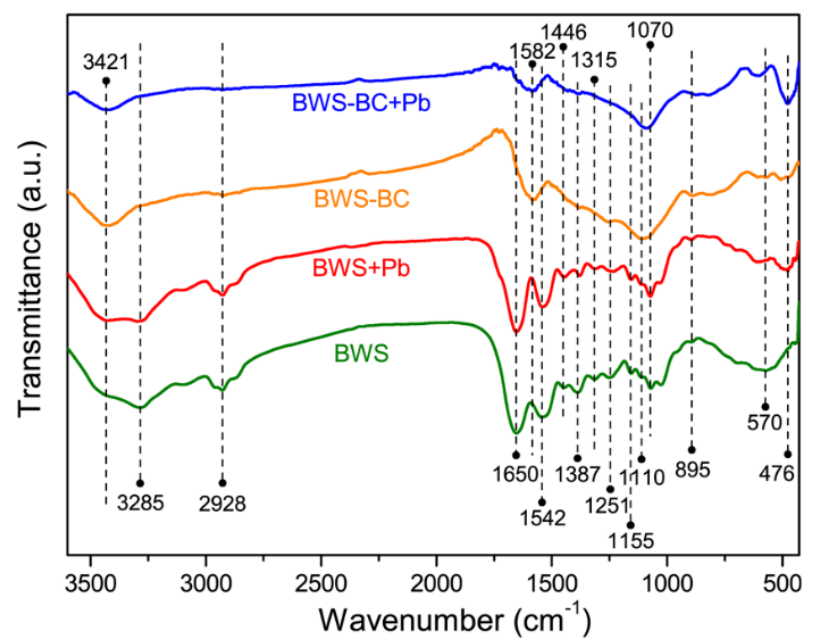

Fig. 4 

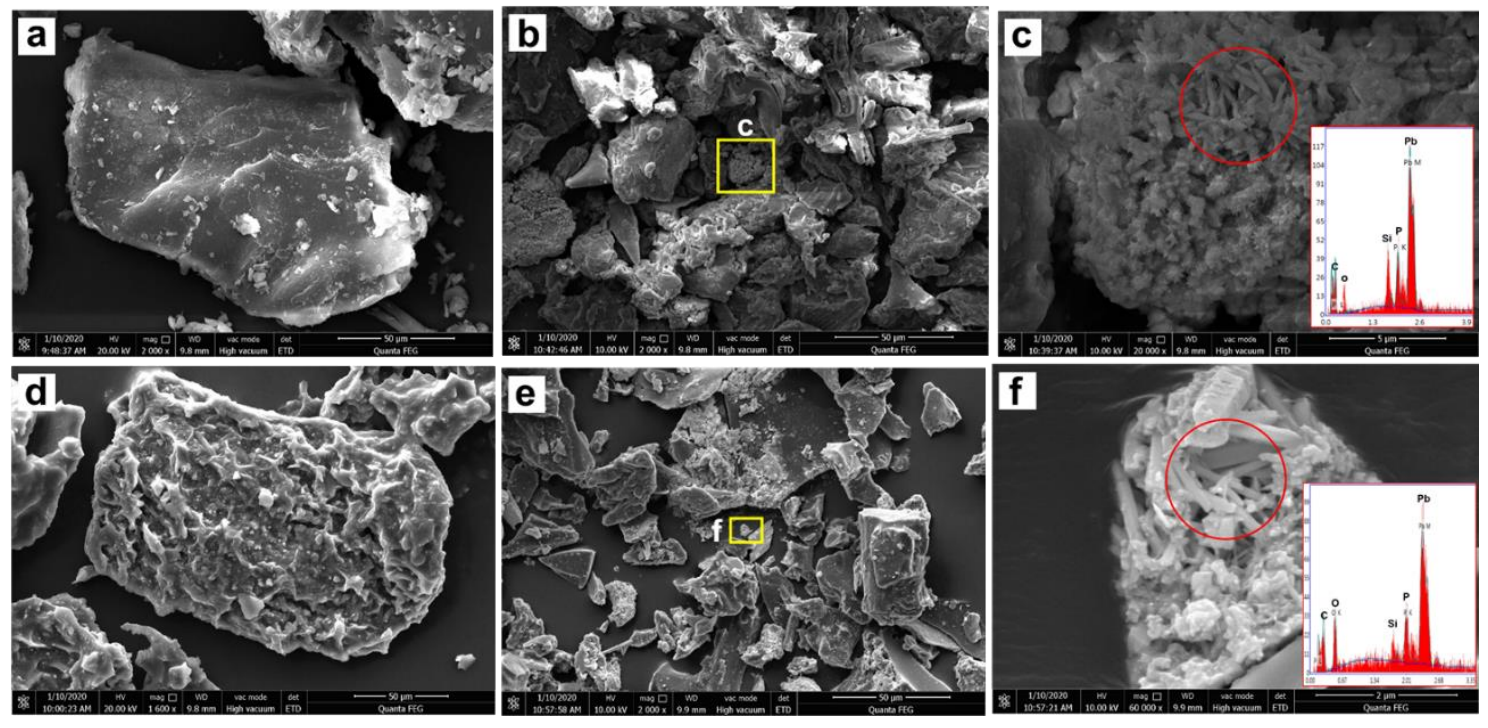

Fig. 5

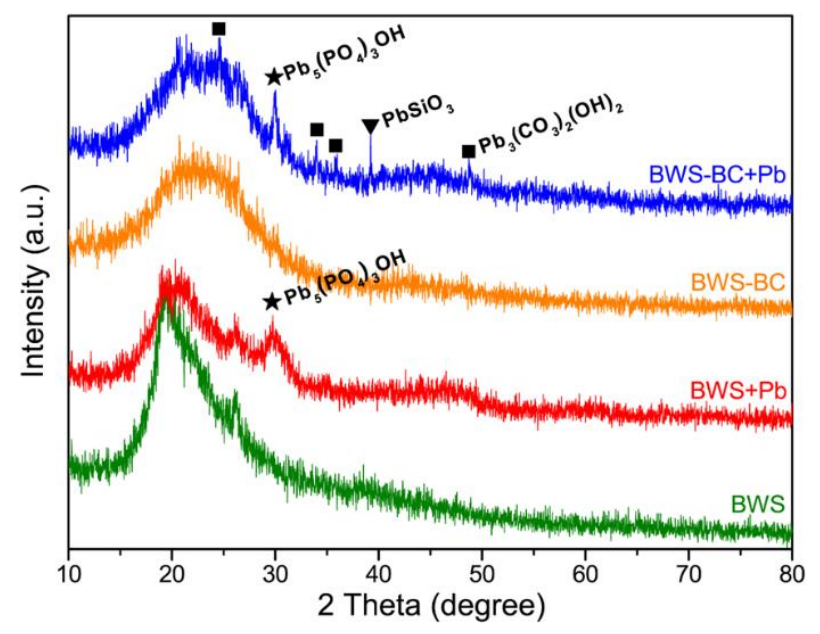

Fig. 6 
Supplementary Materials for

\section{Phosphorus-rich biochar produced through bean-worm skin waste pyrolysis enhances the adsorption of aqueous lead}

Yubo Yan ${ }^{\mathrm{a}, \mathrm{b}}$, Binoy Sarkar ${ }^{\mathrm{c}}$, Lei Zhou ${ }^{\mathrm{a}}$, Ling Zhang ${ }^{\mathrm{d}}$, Qiao Li ${ }^{\mathrm{e}}$, Jianjun Yang ${ }^{\mathrm{b}^{*}}$, Nanthi Bolan ${ }^{\mathrm{f}, \mathrm{g}}$ ${ }^{a}$ School of Chemistry and Chemical Engineering, Huaiyin Normal University, Huai'an 223300, China

${ }^{\mathrm{b}}$ Institute of Environmental and Sustainable Development in Agriculture, Chinese Academy of Agricultural Science, Beijing 100081, China

${ }^{\mathrm{c}}$ Lancaster Environment Centre, Lancaster University, Lancaster, LA1 4YQ, United Kingdom

${ }^{\mathrm{d}}$ School of Health, Jiangsu Food \& Pharmaceutical Science College, Huai'an 223001, China

${ }^{\mathrm{e}}$ School of Environmental and Biological Engineering, Nanjing University of Science and Technology, Nanjing 210094, China

${ }^{\mathrm{f}}$ Global Centre for Environmental Remediation, University of Newcastle, Callaghan Campus, NSW 2308, Australia

${ }^{\mathrm{g} C}$ Cooperative Research Centre for High Performance Soil (Soil CRC), Callaghan, NSW 2308, Australia 


\section{Linearized equations for the kinetic models}

Pseudo-first order model: $\log \left(q_{\mathrm{e}}-q_{\mathrm{t}}\right)=\log q_{\mathrm{e}}-\frac{k_{1} t}{2.303}$

Pseudo-second order model: $\frac{t}{q_{\mathrm{t}}}=\frac{1}{k_{2} q_{\mathrm{e}}^{2}}+\frac{t}{q_{\mathrm{e}}}$

where, $q_{\mathrm{e}}\left(\mathrm{mg} \mathrm{g}^{-1}\right)$ is the equilibrium amount of $\mathrm{Pb}(\mathrm{II})$ adsorbed on BWS and BWS-BC; $q_{\mathrm{t}}(\mathrm{mg}$ $\left.\mathrm{g}^{-1}\right)$ is the amount of $\mathrm{Pb}(\mathrm{II})$ adsorbed at time $t(\mathrm{~min}) ; k_{1}\left(\mathrm{~min}^{-1}\right)$ and $k_{2}\left(\mathrm{~g} \mathrm{mg}^{-1} \mathrm{~min}^{-1}\right)$ are relevant rate constants. What's more, as $t$ in Eq. (2) approaches 0 , the initial adsorption rate $\left(h, \mathrm{mg} \mathrm{g}^{-1}\right.$ $\left.\min ^{-1}\right)$ of $\mathrm{Pb}(\mathrm{II})$ on different adsorbents can be calculated by:

$h=k_{2} q_{\mathrm{e}}^{2}$

\section{Linearized equations for the isotherm models}

Langmuir model: $\frac{C_{\mathrm{e}}}{q_{\mathrm{e}}}=\frac{C_{\mathrm{e}}}{q_{\max }}+\frac{1}{b q_{\max }}$

$$
R_{\mathrm{L}}=\frac{1}{1+b C_{0}}
$$

Freundlich model: $\log q_{\mathrm{e}}=\log K_{\mathrm{F}}+\frac{1}{n} \log C_{\mathrm{e}}$

D-R model: $\ln q_{\mathrm{e}}=\ln q_{\mathrm{m}}-\beta \varepsilon^{2}$

$$
\begin{aligned}
& \varepsilon=R T \ln \left(1+\frac{1}{C_{\mathrm{e}}}\right) \\
& E=\frac{1}{\sqrt{2 \beta}}
\end{aligned}
$$

where, $C_{\mathrm{e}}\left(\mathrm{mg} \mathrm{L}^{-1}\right)$ is the equilibrium $\mathrm{Pb}(\mathrm{II})$ concentration in solution; $q_{\mathrm{e}}\left(\mathrm{mg} \mathrm{g}^{-1}\right)$ is the adsorption amount of BWS and BWS-BC at equilibrium; $q_{\max }\left(\mathrm{mg} \mathrm{g}^{-1}\right)$ is the predicted maximum adsorption capacity of BWS and BWS-BC; $q_{\mathrm{m}}\left(\mathrm{mg} \mathrm{g}^{-1}\right)$ is the theoretical saturation adsorption capacity of BWS and BWS-BC; $b, K_{\mathrm{F}}, n$ and $\beta$ are the constants for each model; $\varepsilon$ and $R\left(8.3145 \mathrm{~J} \mathrm{~mol}^{-1} \mathrm{~K}^{-1}\right)$ are the Polanyi and universal gas potentials, respectively; $T(\mathrm{~K})$ is Kelvin temperature; $E\left(\mathrm{~kJ} \mathrm{~mol}^{-1}\right)$ is the mean free energy of $\mathrm{Pb}(\mathrm{II})$ adsorption on BWS and BWS-BC. 


\section{Van't Hoff equation}

$$
\begin{aligned}
& K=\frac{C_{\mathrm{s}}}{C_{\mathrm{e}}} \\
& \Delta G^{\circ}=-R T \ln K \quad(11) \\
& \ln K=\frac{\Delta S^{\circ}}{R}-\frac{\Delta H^{\circ}}{R T}
\end{aligned}
$$

where, $K$ is the equilibrium constant; $C_{\mathrm{s}}\left(\mathrm{mg} \mathrm{g}^{-1}\right)$ is the equilibrium adsorption capacity of $\mathrm{Pb}$ (II) on BWS and BWS-BC; $C_{\mathrm{e}}\left(\mathrm{mg} \mathrm{L}^{-1}\right)$ is the equilibrium $\mathrm{Pb}(\mathrm{II})$ concentration in solution. 
Table S1 Selected physicochemical properties of BWS and BWS-BC.

\begin{tabular}{ccccccccccc}
\hline Adsorbents & $\begin{array}{c}\text { Yield } \\
(\%)\end{array}$ & $\mathrm{pH}$ & $\begin{array}{c}\text { Ash } \\
(\%)\end{array}$ & $\begin{array}{c}\mathrm{CEC} \\
(\mathrm{cmol} / \mathrm{kg})\end{array}$ & $\begin{array}{c}\mathrm{C} \\
(\%)\end{array}$ & $\begin{array}{c}\mathrm{N} \\
(\%)\end{array}$ & $\begin{array}{c}\mathrm{H} \\
(\%)\end{array}$ & $\begin{array}{c}\mathrm{O} \\
(\%)\end{array}$ & $\begin{array}{c}\mathrm{P} \\
(\mathrm{mg} / \mathrm{kg})\end{array}$ & $\begin{array}{c}\text { SSA } \\
\left(\mathrm{m}^{2} / \mathrm{g}\right)\end{array}$ \\
\hline BWS & - & 5.2 & 4.7 & 0.64 & 43.5 & 14.2 & 10.8 & 29.7 & 6086 & 0.21 \\
BWS-BC & 38.4 & 9.4 & 9.6 & 6.9 & 71.2 & 9.7 & 2.1 & 16.6 & 22762 & 13.5 \\
\hline
\end{tabular}


Table S2 Pseudo-first order and pseudo-second order kinetic parameters for the adsorption of $\mathrm{Pb}(\mathrm{II})$ at $25{ }^{\circ} \mathrm{C}$.

\begin{tabular}{|c|c|c|c|c|c|c|c|}
\hline \multirow{2}{*}{ Adsorbents } & \multirow{2}{*}{$\begin{array}{c}q_{\mathrm{e}, \exp } \\
\left(\mathrm{mg} \mathrm{g}^{-1}\right)\end{array}$} & \multicolumn{3}{|c|}{ Pseudo-first order kinetic } & \multicolumn{3}{|c|}{ Pseudo-second order kinetic } \\
\hline & & $\begin{array}{c}k_{1} \\
\left(\min ^{-1}\right)\end{array}$ & $\begin{array}{c}q_{\mathrm{e}, \mathrm{cal}} \\
\left(\mathrm{mg} \mathrm{g}^{-1}\right)\end{array}$ & $R^{2}$ & $\begin{array}{c}k_{2} \\
\left(\mathrm{~g} \mathrm{mg}^{-1} \mathrm{~min}^{-1}\right)\end{array}$ & $\begin{array}{c}q_{\mathrm{e}, \mathrm{cal}} \\
\left(\mathrm{mg} \mathrm{g}^{-1}\right)\end{array}$ & $R^{2}$ \\
\hline BWS & 32.82 & $3.0 \times 10^{-3}$ & 21.41 & 0.9613 & $4.8 \times 10^{-4}$ & 33.78 & 0.9982 \\
\hline BWS-BC & 43.98 & $5.5 \times 10^{-3}$ & 20.98 & 0.9103 & $8.2 \times 10^{-4}$ & 45.05 & 0.9999 \\
\hline
\end{tabular}


Table S3 Langmuir, Freundlich and Dubinin-Radushkevich isotherm parameters for the adsorption of $\mathrm{Pb}(\mathrm{II})$ at $25^{\circ} \mathrm{C}$.

\begin{tabular}{|c|c|c|c|c|c|c|c|c|c|}
\hline \multirow{2}{*}{ Adsorbents } & \multicolumn{3}{|l|}{ Langmuir } & \multicolumn{3}{|c|}{ Freundlich } & \multicolumn{3}{|c|}{ Dubinin-Radushkevich } \\
\hline & $q_{\max }\left(\mathrm{mg} \mathrm{g}^{-1}\right)$ & $b$ & $R^{2}$ & $K_{\mathrm{F}}$ & $1 / n$ & $R^{2}$ & $q_{\mathrm{m}}\left(\mathrm{mg} \mathrm{g}^{-1}\right)$ & $E\left(\mathrm{~kJ} \mathrm{~mol}^{-1}\right)$ & $R^{2}$ \\
\hline BWS & 45.45 & 0.0860 & 0.9930 & 11.69 & 0.2597 & 0.8719 & 89.94 & 14.67 & 0.8988 \\
\hline BWS-BC & 61.73 & 0.1314 & 0.9934 & 17.80 & 0.2489 & 0.8680 & 118.1 & 15.52 & 0.8910 \\
\hline
\end{tabular}


1 Table S4 Reported maximum adsorption capacities of $\mathrm{Pb}(\mathrm{II})$ by other adsorbents.

2

\begin{tabular}{lll}
\hline Adsorbents & $q_{\max }\left(\mathrm{mg} \mathrm{g}^{-1}\right)$ & References \\
\hline Raw biomasses & & \\
\hline BWS & 45.45 & This study \\
Wheat straw & 46.33 & Cao et al., 2019 \\
Peanut shell & 38.91 & Taşar et al., 2014 \\
Sphagnum moss peat & 30.70 & Ho et al., 1996 \\
Almond shell & 26.55 & Ronda et al., 2013 \\
Sawdust & 21.05 & Li et al., 2007 \\
Corn cob & 16.22 & Tan et al., 2010 \\
Banana peel & 2.18 & Anwar et al., 2010 \\
\hline Biochars & & \\
\hline BWS-BC & 61.73 & This study \\
Gingko leaf biochar & 50.62 & Lee et al., 2019 \\
Camphor leaves biochar & 39.06 & Wang et al., 2018 \\
Orange peel biochar & 27.86 & Abdelhafez and Li, 2016 \\
Hickory biochar & 16.3 & Ding et al., 2016 \\
Peanut shell biochar & 11.05 & Lee et al., 2019 \\
Rice husk biochar & 2.40 & Liu and Zhang, 2009 \\
Pistachio shell biochar & 1.22 & Komnitsas et al., 2016 \\
\hline
\end{tabular}

Table S5 Thermodynamic parameters for the adsorption of $\mathrm{Pb}(\mathrm{II})$.

\begin{tabular}{ccccc}
\hline Adsorbents & $T\left({ }^{\circ} \mathrm{C}\right)$ & $\triangle \mathrm{G}^{\mathrm{o}}\left(\mathrm{kJ} \mathrm{mol}^{-1}\right)$ & $\triangle \mathrm{H}^{\mathrm{o}}\left(\mathrm{kJ} \mathrm{mol}^{-1}\right)$ & $\triangle \mathrm{S}^{\mathrm{o}}\left(\mathrm{kJ} \mathrm{mol}^{-1} \mathrm{~K}^{-1}\right)$ \\
\hline BWS & 10 & -0.28 & & \\
& 25 & -3.48 & 86.84 & 0.31 \\
& 40 & -9.56 & & \\
BWS-BC & 10 & -4.31 & & 0.54 \\
& 25 & -7.10 & 149.74 & \\
\hline
\end{tabular}




\section{References}

Abdelhafez, A.A., Li, J., 2016. Removal of Pb(II) from aqueous solution by using biochars derived from sugar cane bagasse and orange peel. J. Taiwan Inst. Chem. Eng. 61, 367-375.

Anwar, J., Shafique, U., Waheed-uz-Zaman, Salman, M., Dar, A., Anwar, S., 2010. Removal of $\mathrm{Pb}(\mathrm{II})$ and $\mathrm{Cd}(\mathrm{II})$ from water by adsorption on peels of banana. Bioresource Technol. 101, 1752-1755.

Cao, Y., Xiao, W., Shen, G., Ji, G., Zhang, Y., Gao, C., Han, L., 2019. Carbonization and ball milling on the enhancement of $\mathrm{Pb}(\mathrm{II})$ adsorption by wheat straw: Competitive effects of ion exchange and precipitation. Bioresource Technol. 273, 70-76.

Ding, Z., Wan, Y., Hu, X., Wang, S., Zimmerman, A.Z., Gao, B., 2016. Sorption of lead and methylene blue onto hickory biochars from different pyrolysis temperatures: Importance of physicochemical properties. J. Ind. Eng. Chem. 37, 261-267.

Ho, Y.S., Wase, D.A.J., Forster, C.F., 1996. Kinetic studies of competitive heavy metal adsorption by sphagnum moss peat. Environ. Technol. 17, 71-77.

Komnitsas, K., Zaharaki, D., Pyliotis, I., Vamvuka, D., Bartzas, G., 2015. Assessment of pistachio Shell biochar quality and its potential for adsorption of heavy metals. Waste Biomass Valori. 6, 805-816.

Lee, M., Park, J.H., Chung, J.W., 2019. Comparison of the lead and copper adsorption capacities of plant source materials and their biochars. J. Environ. Manage. 236, 118-124.

Li, Q., Zhai, J., Zhang, W., Wang, M., Zhou, J., 2007. Kinetic studies of adsorption of Pb(II), $\mathrm{Cr}(\mathrm{III})$ and $\mathrm{Cu}$ (II) from aqueous solution by sawdust and modified peanut husk. J. Hazard. Mater. 141, 163-167.

Liu, Z., Zhang, F., 2009. Removal of lead from water using biochars prepared from hydrothermal liquefaction of biomass. J. Hazard. Mater. 167, 933-939.

Ronda, A., Martín-Lara, M., Dionisio, E., Blázquez, G., Calero, M., 2013. Effect of lead in biosorption of copper by almond shell. J. Taiwan Inst. Chem. Eng. 44, 466-473.

Tan, G., Yuan, H., Liu, Y., Xiao, D., 2010. Removal of lead from aqueous solution with native and chemically modified corncobs. J. Hazard. Mater. 174, 740-745.

Taşar, Ş., Kaya, F., Özer, A., 2014. Biosorption of lead(II) ions from aqueous solution by peanut 

shells: Equilibrium, thermodynamic and kinetic studies. J. Environ. Chem. Eng. 2, 1018 1026.

40 Wang, C., Wang, H., Cao, Y., 2018. Pb(II) sorption by biochar derived from Cinnamomum camphora and its improvement with ultrasound-assisted alkali activation. Colloid. Surface. A 556, 177-184. 